\title{
Bioenergetic study of murine hepatic tissue treated in vitro with atorvastatin
}

\author{
Ali S Alfazari ${ }^{1 *}$, Bayan Al-Dabbagh, Saeeda Almarzooqi ${ }^{2}$, Alia Albawardi $^{2}$ and Abdul-Kader Souid ${ }^{3}$
}

\begin{abstract}
Atorvastatin (a 3-hydroxy-3-methylglutaryl coenzyme-A reductase inhibitor) is a widely used cholesterol-lowering drug, which is recognized for its potential hepatotoxicity. This study investigated in vitro effects of this agent on hepatic tissue respiration, ATP content, caspase activity, urea synthesis and histology. Liver fragments from Taylor Outbred and $\mathrm{C} 57 \mathrm{BI} / 6$ mice were incubated at $37^{\circ} \mathrm{C}$ in Krebs-Henseleit buffer continuously gassed with $95 \% \mathrm{O}_{2}: 5 \%$ $\mathrm{CO}_{2}$ in the presence and absence of atorvastatin. Phosphorescence $\mathrm{O}_{2}$ analyzer that measured dissolved $\left[\mathrm{O}_{2}\right]$ as a function of time was used to monitor cellular mitochondrial $\mathrm{O}_{2}$ consumption. The caspase-3 substrate $\mathrm{N}$-acetyl-aspglu-val-asp-7-amino-4-methylcoumarin was used to monitor caspase activity. The rates of hepatocyte respiration $\left(\mu \mathrm{M} \mathrm{O}_{2} \mathrm{~min}^{-1} \mathrm{mg}^{-1}\right)$ in untreated samples were $0.15 \pm 0.07(\mathrm{n}=31)$. The corresponding rates for samples treated with $50 \mathrm{nM}$ (therapeutic concentration), $150 \mathrm{nM}$ or $1.0 \mu \mathrm{M}$ atorvastatin for $\leq 13 \mathrm{~h}$ were $0.13 \pm 0.05(\mathrm{n}=19), p=0.521$. The contents of hepatocyte ATP $\left(\mathrm{pmol}^{-1} \mathrm{mg}^{-1}\right.$ ) in untreated samples were $40.3 \pm 14.0$ and in samples treated with $1.0 \mu \mathrm{M}$ atorvastatin for $\leq 4.5 \mathrm{~h}$ were $48.7 \pm 23.9(p=0.7754)$. The concentrations of urea $\left(\mathrm{mg} / \mathrm{dL} \mathrm{mg}^{-1}\right.$, produced over $50 \mathrm{~min}$ ) for untreated samples were $0.061 \pm 0.020(\mathrm{n}=6)$ and for samples treated with $1.0 \mu \mathrm{M}$ atorvastatin for $\leq 6 \mathrm{~h}$ were $0.072 \pm 0.022(n=6), p=0.3866$. Steadily, hepatocyte caspase activity and histology were unaffected by treatments with up to $1.0 \mu \mathrm{M}$ atorvastatin for $\leq 6 \mathrm{~h}$. Thus, the studied murine model showed preserved hepatocyte function and structure in the presence of high concentrations of atorvastatin.
\end{abstract}

Keywords: Statins, Mitochondria, Respiration, Caspases, Apoptosis

\section{Background}

Statins, 3-hydroxy-3-methylglutaryl coenzyme-A reductase inhibitors, are the most effective class of drugs that treat hypercholesterolemia. These agents reduce hepatocyte cholesterol, which results in up-regulation of the low-density lipoprotein (LDL) receptors and increased clearance of LDL-cholesterol from the plasma. Atorvastatin, $(3 R, 5 R)-7$-[2-(4-fluorophenyl)3-phenyl-4-(phenylcarbamoyl)-5-propan-2-ylpyrrol1-yl] -3,5-dihydroxyheptanoic acid, is considered "best-in-class" for meeting the recommended treatment guidelines [1].

Elevations of liver alanine and aspartate aminotransferases (ALT and AST) are well-recognized adverse events of atorvastatin [2-4], occurring in about $0.5 \%$ of patients, usually in the first few months of therapy $[5,6]$. Since other lipid-lowering compounds also increase liver aminotransferases, it has been debated whether statin-

\footnotetext{
* Correspondence: a.almelaih@uaeu.ac.ae

'Department of Internal Medicine, United Arab Emirates University, Al Ain, Abu Dhabi, United Arab Emirates

Full list of author information is available at the end of the article
}

associated elevated transaminases are due to hepatotoxicity or a reaction to reduced cholesterol [7]. More recent studies have shown statins are well tolerated by patients with primary biliary cirrhosis, hepatitis $\mathrm{C}$ and non-alcoholic steatohepatitis [8-10]. Furthermore, a few short-term studies showed statins improved hepatic inflammation in patients with non-alcoholic fatty liver disease [11]. In a prospective, double blind trial of 326 patients with chronic liver disease, fewer patients in the pravastatin group had elevations in ALT compared to placebo $(7.5 \%$ vs. $12.5 \%, p=0.13)$ [12]. The recent post hoc analysis of safety of atorvastatin in the Greek Atorvastatin and Coronary Heart Disease Evaluation (GREACE) study showed atorvastatin significantly ameliorated elevations of AST and ALT [13]. Other reports in humans and animals showed hepatotoxicities of statins [14], including caspase activation (apoptosis) and induction of mitochondrial disturbances [15]. These toxicities could stem from confounding factors, such
C Biomed Central

(C) 2013 Alfazari et al.; licensee BioMed Central Ltd. This is an Open Access article distributed under the terms of the Creative Commons Attribution License (http://creativecommons.org/licenses/by/2.0), which permits unrestricted use, distribution, and reproduction in any medium, provided the original work is properly cited. 
idiosyncratic reactions, hypercholesterolemia, concomitant medications and co-morbidities (e.g., diabetes mellitus).

The term "cellular bioenergetics" implies the biochemical processes involved in energy metabolism (energy conversion or transformation), and the term "cellular respiration" (mitochondrial $\mathrm{O}_{2}$ consumption) describes the delivery of metabolites and $\mathrm{O}_{2}$ to the mitochondria, the oxidation of reduced metabolic fuels with passage of electrons to $\mathrm{O}_{2}$, and the synthesis of ATP. Impaired bioenergetics or respiration entails interferences with any of these processes.

Apoptosis describes the highly regulated mechanisms responsible for cellular responses to injuries and adverse biological signals. This process produces deleterious morphological and biochemical changes, including mitochondrial disturbances that may lead to cell death [16]. Caspases, cysteine aspartate-directed proteases and members of the interleukin-1 $\beta$-converting enzyme (ICE), are key executers of apoptosis. Intracellular caspase activity can be monitored using the caspase- 3 synthetic substrate $N$-cetyl-asp-glu-val-asp-7-amino-(4-methyl- coumaryl-7amide) (Ac-DEVD-AMC). Caspase- 3 is involved in proteolysis of proteins, including poly(ADP ribose) polymerase. The enzyme cleaves at the C-terminal to $\mathrm{Asp}^{216}$ in the asp-glu-val-asp sequence. This 4-amino-acid motif has been utilized for the highly specific caspase-3 substrate Ac-DEVD-AMC. Caspase-3 cleaves the tetrapeptide between $\mathrm{D}$ and $\mathrm{AMC}$, releasing the fluorogenic moiety 7 amino-4-methylcoumarin (AMC). The latter can be separated on HPLC and detected by fluorescence with a great accuracy [17].

The primary aim of the study here was to investigate the effects of atorvastatin on hepatocyte bioenergetics and caspase activity. The described in vitro murine system allowed accurate assessment of multiple hepatic biomarkers as a function of time using murine liver tissue. The results show liver tissue function and structure are well preserved in the presence of high concentrations of atorvastatin.

\section{Materials and methods \\ Reagents}

Atorvastatin was purchased from Selleck Chemicals (Houston, TX, USA). Pd(II) complex of meso-tetra-(4sulfonatophenyl)-tetrabenzoporphyrin (Pd phosphor) was purchased from Porphyrin Products (Logan, UT). A lyophilized powder of caspase inhibitor I [ $N$-benzyloxycarbonylval-ala-asp(O-methyl)-fluoromethylketone, zVAD-fmk, $m . w .=467.5$, a pan-caspase inhibitor] was purchased from Calbiochem (La Jolla, CA). Ac-DEVD-AMC ( $N$ acetyl-asp-glu-val-asp-7- amino-4-methylcoumarin; $m$. $w$. = 675.64; caspase-3 substrate) was purchased from Axxora LLC (San Diego, CA). Complete ${ }^{\circledR}$ protease inhibitor cocktail was purchased from Roche Applied Science (Indianapolis, IN). Glucose (anhydrous), endotoxinand fatty acid-free bovine serum albumin and remaining reagents were bought from Sigma-Aldrich (St. Louis, MO).

The pan-caspase inhibitor (zVAD-fmk) solution $(2.14 \mathrm{mM})$ was made by dissolving $1.0 \mathrm{mg}$ in $1.0 \mathrm{~mL}$ dimethyl sulfoxide and stored at $-20^{\circ} \mathrm{C}$. Ac-DEVD-AMC solution (7.4 mM) was made by dissolving $5.0 \mathrm{mg}$ in $1.0 \mathrm{~mL}$ dimethyl sulfoxide and stored at $-20^{\circ} \mathrm{C}$. Pd phosphor solution $(2.5 \mathrm{mg} / \mathrm{mL}=2 \mathrm{mM})$ was prepared in $\mathrm{dH}_{2} \mathrm{O}$ and stored in aliquots at $-20^{\circ} \mathrm{C}$. NaCN solution $(1.0 \mathrm{M})$ was prepared in $\mathrm{dH}_{2} \mathrm{O}$; the $\mathrm{pH}$ was adjusted to $\sim 7.0$ with $12 \mathrm{~N} \mathrm{HCl}$ and stored at $-20^{\circ} \mathrm{C}$. Glucose oxidase, $10 \mathrm{mg} / \mathrm{mL}$ in $\mathrm{dH}_{2} \mathrm{O}$, was stored at $-20^{\circ} \mathrm{C}$. One tablet of Complete ${ }^{\circledR}$ protease inhibitor cocktail was dissolved in $1.0 \mathrm{~mL}$ Water-For-Injection and stored at $-20^{\circ} \mathrm{C}$.

\section{Mice}

Male Taylor Outbred (TO, age: 9-10 weeks, weight: 3035 g) and $\mathrm{C} 57 \mathrm{Bl} / 6$ (age: 9-10 weeks, weight: 20-22 g) mice were maintained at an animal facility that was in compliance with NIH guidelines (http:/grants.nih.gov/ grants/olaw/references/phspol.htm). The mice were purchased from the Jackson Laboratory (Bar Harbor, ME). All mice were housed in rooms maintained at $22^{\circ} \mathrm{C}$ with $\sim 60 \%$ relative humidity and a 12 -hr light/dark cycle. All mice had ad libitum access to standard rodent chow and filtered water. All protocols here received approval from the Animal Ethics Committee-United Arab Emirates University-College of Medicine and Health Sciences.

\section{Liver tissue}

Mice were anesthetized by sevoflurane inhalation (100 $\mu \mathrm{L}$ per 10 g body weight). Liver specimens ( 20 to $30 \mathrm{mg}$ ) were collected using a 4-mm human skin biopsy punch (Miltex $\mathrm{GmbH}$, Germany) and immediately immersed in $50 \mathrm{~mL}$ ice-cold modified Krebs-Henseleit (KH) buffer (115 mM NaCl, $25 \mathrm{mM} \mathrm{NaHCO} 3,1.23 \mathrm{mM}$ $\mathrm{NaH}_{2} \mathrm{PO}_{4}, 1.2 \mathrm{mM} \mathrm{Na} \mathrm{SO}_{4}, 5.9 \mathrm{mM} \mathrm{KCl}, 1.0 \mathrm{mM}$ EDTA, $1.18 \mathrm{mM} \mathrm{MgCl} 2,10 \mathrm{mM}$ glucose, and $0.5 \mu \mathrm{L} / \mathrm{mL}$ Complete $^{\circledR}$ protease inhibitor cocktail, $\mathrm{pH}$ 7.5) continuously gassed with $95 \% \mathrm{O}_{2}: 5 \% \mathrm{CO}_{2}$ [18].

The samples were then incubated in vitro at $37^{\circ} \mathrm{C}$ in $50 \mathrm{~mL}$ in $\mathrm{KH}$ buffer $(115 \mathrm{mM} \mathrm{NaCl}, 25 \mathrm{mM} \mathrm{NaHCO}$, $1.23 \mathrm{mM} \mathrm{NaH} \mathrm{PO}_{4}, 1.2 \mathrm{mM} \mathrm{Na} \mathrm{SO}_{4}, 5.9 \mathrm{mM} \mathrm{KCl}$, $1.25 \mathrm{mM} \mathrm{CaCl}_{2}, 1.18 \mathrm{mM} \mathrm{MgCl}_{2}$, and $10 \mathrm{mM}$ glucose, pH 7.5) supplemented with $0.5 \mu \mathrm{L} / \mathrm{mL}$ Complete ${ }^{\circledR}$ protease inhibitor cocktail and continuously gassed with $95 \% \mathrm{O}_{2}: 5 \% \mathrm{CO}_{2}$. For the $\mathrm{O}_{2}$ measurement, specimens were placed in $1.0 \mathrm{~mL} \mathrm{KH}$ buffer (air-saturated) containing $0.5 \%$ fatty acids-free bovine albumin and $3 \mu \mathrm{M}$ Pd phosphor. Specimens were also processed for measuring caspase activity, urea synthesis and histology as described below. 


\section{Oxygen measurement}

Phosphorescence oxygen analyzer was used to monitor $\mathrm{O}_{2}$ consumption by liver specimens $[18,19] . \mathrm{O}_{2}$ detection was performed with the aid of Pd phosphor that had absorption maximum at $625 \mathrm{~nm}$ and phosphorescence maximum at $800 \mathrm{~nm}$. Samples were exposed to light flashes (600 per $\mathrm{min}$ ) from a pulsed light-emitting diode array with peak output at $625 \mathrm{~nm}$ (OTL630A-5-10-66-E, Opto Technology, Inc., Wheeling, IL). Emitted phosphorescent light was detected by a Hamamatsu photomultiplier tube (928) after first passing it through a wide-band interference filter centered at $800 \mathrm{~nm}$. The amplified phosphorescence decay was digitized at $1.0 \mathrm{MHz}$ by a $20-\mathrm{MHz}$ A/D converter (Computer Boards, Inc., Mansfield, MA).

A program was developed using Microsoft Visual Basic 6, Microsoft Access Database 2007, and Universal Library components (Universal Library for Measurements Computing Devices; http://www.mccdaq.com/daq-software/universal-library.aspx). It allowed direct reading from the PCI-DAS 4020/12 I/O Board (PCI-DAS 4020/12 I/O Board; http:// www.mccdaq.com/pci-data-acquisition/PCI-DAS4020-12. aspx). The pulse detection was accomplished by searching for 10 phosphorescence intensities $>1.0$ volt (by default). Peak detection was accomplished by searching for the highest 10 data points of a pulse and choosing the data point closest to the pulse decay curve [20].

The phosphorescence decay rate $(1 / \tau)$ was characterized by a single exponential; $\mathrm{I}=\mathrm{Ae}^{-t / \tau}$, where $\mathrm{I}=\mathrm{Pd}$ phosphor phosphorescence intensity. The values of $1 / \tau$ were linear with dissolved $\mathrm{O}_{2}: 1 / \tau=1 / \tau^{\mathrm{o}}+k_{q}\left[\mathrm{O}_{2}\right]$, where $1 / \tau=$ the phosphorescence decay rate in the presence of $\mathrm{O}_{2}, 1 / \tau^{\mathrm{o}}=$ the phosphorescence decay rate in the absence of $\mathrm{O}_{2}$, and $k_{\mathrm{q}}=$ the second-order $\mathrm{O}_{2}$ quenching rate constant in $\mathrm{s}^{-1} \cdot \mu \mathrm{M}^{-1}$.

Respiration was measured at $37^{\circ} \mathrm{C}$ in $1-\mathrm{mL}$ sealed vials. Mixing was with the aid of parylene-coated stirring bars. In vials sealed from air, $\left[\mathrm{O}_{2}\right]$ decreased linearly with time, indicating the kinetics of mitochondrial $\mathrm{O}_{2}$ consumption was zero-order. The rate of respiration $(k$, in $\mu \mathrm{M} \mathrm{O}_{2} \mathrm{~min}^{-1}$ ) was thus the negative of the slope $\mathrm{d}\left[\mathrm{O}_{2}\right] /$ $\mathrm{d} t$. $\mathrm{NaCN}$ inhibited respiration, confirming $\mathrm{O}_{2}$ was consumed in the mitochondrial respiratory chain.

The calibration reaction contained PBS with $3 \mu \mathrm{M}$ Pd phosphor, $0.5 \%$ fat-free albumin, $50 \mu \mathrm{g} / \mathrm{mL}$ glucose oxidase and various concentrations of $\beta$-glucose. $\left[\mathrm{O}_{2}\right]$ was calculated using, $1 / \tau=1 / \tau^{\mathrm{o}}+k_{q}\left[\mathrm{O}_{2}\right]$ [21]. Rates of cellular respiration were normalized per $\mathrm{mg}$ of liver tissue (i.e., expressed as $\mu \mathrm{M} \mathrm{O}_{2}$ consumed per min per mg liver tissue).

\section{ATP content}

Liver fragments were homogenized in ice-cold $2 \%$ trichloroacetic acid for $2 \mathrm{~min}$ and neutralized with $100 \mathrm{mM}$ Tris-acetate, $2 \mathrm{mM}$ EDTA, $\mathrm{pH}$ 7.75. The supernatant was collected by centrifugation $\left(1000 \times g\right.$ at $4^{\circ} \mathrm{C}$ for $5 \mathrm{~min}$ ) and stored at $-20^{\circ} \mathrm{C}$ until analysis. The $\mathrm{pH}$ of samples was adjusted to 7.75 immediately before ATP determination. ATP concentration was measured using the Enliten ATP Assay System (Bioluminescence Detection Kit, Promega, Madison, WI). Briefly, $2.5 \mu \mathrm{L}$ of the acid-soluble supernatant was added to $25 \mu \mathrm{L}$ of the luciferin/luciferase reagent. The luminescence intensity was measured at $25^{\circ} \mathrm{C}$ using Glomax Luminometer (Promega, Madison, WI). The ATP standard curve was linear from $10 \mathrm{pM}$ to $100 \mathrm{nM}\left(R^{2}>0.9999\right)$.

\section{Intracellular caspase activity}

Liver specimens were incubated at $37^{\circ} \mathrm{C}$ in oxygenated $\mathrm{KH}$ buffer containing $37 \mu \mathrm{M}$ Ac-DEVD-AMC with and without $32 \mu \mathrm{M}$ zVAD-fmk (final volume, $0.5 \mathrm{~mL}$ ). The tissue was then disrupted by vigorous homogenization and 10 passages through a $27-G$ needle. The Ac-DEVD-AMC cleavage reaction was quenched with tissue disruption, mainly because caspases became inactive due to dilution. The supernatant was collected by centrifugation $(16,300 \mathrm{~g}$ for $90 \mathrm{~min}$ ) through a Microcentrifuge Filter (nominal molecular weight limit $=10,000$ Dalton, Sigma ${ }^{\odot}$ ), separated on HPLC, and analyzed for the free fluorogenic AMC moiety. The elution time for AMC was about $5.0 \mathrm{~min}$.

\section{HPLC}

The analysis was performed on a Waters 1525 reversedphase HPLC system (Spectra Lab Scientific Inc, Alexandria, VA) that consisted of manual injector, pump and fluorescence detector. The excitation wavelength used was $380 \mathrm{~nm}$ and the emission wavelength $460 \mathrm{~nm}$. Solvents A and $\mathrm{B}$ were HPLC-grade $\mathrm{CH}_{3} \mathrm{OH}: \mathrm{dH}_{2} \mathrm{O}$ (1:1; isocratic). The Ultrasphere IP column $(4.6 \times 250 \mathrm{~mm}$, Beckman $)$ was operated at $25^{\circ} \mathrm{C}$ at $1.0 \mathrm{~mL} / \mathrm{min}$. The run time was $20 \mathrm{~min}$. The injection volume was $50 \mu \mathrm{L}$.

\section{Urea synthesis}

Liver specimens were incubated at $37^{\circ} \mathrm{C}$ in $50 \mathrm{~mL} \mathrm{KH}$ buffer (continuously gassed with $95 \% \mathrm{O}_{2}: 5 \% \mathrm{CO}_{2}$ ) with and without $1.0 \mu \mathrm{M}$ atorvastatin for up to $6 \mathrm{~h}$. Specimens were then removed from the incubation solution every $60 \mathrm{~min}$ and placed in $1.0 \mathrm{~mL} \mathrm{KH}$ buffer supplemented with $10 \mathrm{mM} \mathrm{NH}_{4} \mathrm{Cl}$ and $2.5 \mathrm{mM}$ ornithine. The reactions were allowed to continue at $37^{\circ} \mathrm{C}$ for $50 \mathrm{~min}$ with continuous gassing as above. At the end of the incubation period, the solutions were analyzed for urea as described [22]. Blood urea nitrogen (BUN, $\mathrm{mmol} / \mathrm{L}$ ) was measured using standard laboratory methods with an LX20 multiple automated analyzer (Beckman Coulter, CA, USA). For conversion, BUN $(\mathrm{mg} / \mathrm{dL})=$ BUN $(\mathrm{mmol} / \mathrm{L}) \div 0.357$; Urea $(\mathrm{mg} / \mathrm{dL})=$ BUN $(\mathrm{mg} / \mathrm{dL}) \times 2.14$. 


\section{Histology}

Liver samples were fixed in $10 \%$ neutral formalin, dehydrated in increasing concentrations of ethanol, cleared with xylene and embedded in paraffin. Fourmicrometer sections were prepared from paraffin blocks and stained with hematoxylin and eosin.

\section{Statistical analysis}

Data were analyzed using SPSS statistical package (version 19). The nonparametric test (2 independent variables) Mann-Whitney was used to compare treated and untreated samples. Respiration rates $\left(k_{c}\right.$, in $\mu \mathrm{M} \mathrm{O} \mathrm{O}_{2} \mathrm{~min}^{-1}$ $\mathrm{mg}^{-1}$ ), cellular ATP content ( $\mathrm{pmol} \mathrm{mg} \mathrm{m}^{-1}$ ), AMC peak areas (arbitrary unit $\mathrm{mg}^{-1}$ ) and urea ( $\mathrm{mg} / \mathrm{dL}$ per mg liver tissue) for untreated samples were compared with those for treated samples.

\section{Results}

Bioenergetics of liver tissue treated with atorvastatin To assess the effects of atorvastatin on liver tissue bioenergetics, specimens from ten Taylor Outbred (TO) mice and three $\mathrm{C} 57 \mathrm{Bl} / 6$ mice were incubated at $37^{\circ} \mathrm{C}$ with $50 \mathrm{nM}$ (therapeutic concentration; Maier et al. [23]), $150 \mathrm{nM}$ or $1.0 \mu \mathrm{M}$ atorvastatin and analyzed for cellular $\mathrm{O}_{2}$ consumption and ATP content as a function of time. Results of representative experiments are shown in Figure 1.

In Figure $1 \mathrm{~A}-\mathrm{B}$, liver specimens from $\mathrm{TO}$ mice were incubated at $37^{\circ} \mathrm{C}$ in $50 \mathrm{~mL} \mathrm{KH}$ buffer (continuously gassed with $95 \% \mathrm{O}_{2}: 5 \% \mathrm{CO}_{2}$ ) with and without $150 \mathrm{nM}$ atorvastatin for up to $6 \mathrm{~h}$. Samples were alternatively removed from the incubation mixture and processed for $\mathrm{O}_{2}$ measurement at $37^{\circ} \mathrm{C}$. The rate of respiration $(k, \mu \mathrm{M} \mathrm{O}$ $\min ^{-1}$ ) was set as the negative of the slope of $\left[\mathrm{O}_{2}\right] v s . t$. The values of $k_{c}\left(\mu \mathrm{M} \mathrm{O}_{2} \mathrm{~min}^{-1} \mathrm{mg}^{-1}\right.$; mean $\left.\pm \mathrm{SD}\right)$ for untreated samples were $0.18 \pm 0.06(\mathrm{n}=5$, for $t$ from 1.8 to $5.3 \mathrm{~h})$ and for treated samples $0.18 \pm 0.05(\mathrm{n}=3$, for $t$ from 1.1 to $3.7 \mathrm{~h}), p=0.9737$.

Liver samples were also incubated as above with and without $50 \mathrm{nM}$ atorvastatin. The value of $k_{c}$ for untreated tissue was $0.15 \mu \mathrm{M} \mathrm{O}_{2} \mathrm{~min}^{-1} \mathrm{mg}^{-1}(t=1.4 \mathrm{~h})$ and for treated tissue $0.15 \mu \mathrm{M} \mathrm{O}_{2} \mathrm{~min}^{-1} \mathrm{mg}^{-1}(t=2.2 \mathrm{~h})$. In 10 independent experiments involving incubations with $50 \mathrm{nM}, 150 \mathrm{nM}$ or $1.0 \mu \mathrm{M}$ atorvastatin for up to $13 \mathrm{~h}$, the rates of respiration for untreated specimens were $0.15 \pm 0.07$ ( $\mathrm{n}=31$ runs) and for treated specimens $0.13 \pm 0.05$ ( $\mathrm{n}=19$ runs), $p=0.521$.

In $\mathrm{C} 57 \mathrm{Bl} / 6$ strain, the value of $k_{c}$ for untreated tissue was $0.10 \pm 0.03(1.8<t<5.3 \mathrm{~h}, \mathrm{n}=5)$ and for tissue treated with $1.0 \mu \mathrm{M}$ atorvastatin $0.11 \pm 0.04$ (for $t$ from 1.1 to $3.7 \mathrm{~h}$, $\mathrm{n}=4$ ). In another experiment, the value of $k_{c}$ for untreated tissue was $0.12 \pm 0.05$ (for $t$ from 1.3 to $5.9 \mathrm{~h}, \mathrm{n}=4$ ) and treated tissue $0.12 \pm 0.04$ (for $t$ from 0.5 to $4.4 \mathrm{~h}, \mathrm{n}=3$ ). Thus, hepatocyte respiration was preserved in the presence of high doses of atorvastatin for up to $13 \mathrm{~h}$.
In Figure $1 C$-D, liver samples were incubated as above with and without $1.0 \mu \mathrm{M}$ atorvastatin for up to $6.5 \mathrm{~h}$ and processed for measurements of cellular respiration and ATP content. The results are plotted as a function of incubation time in Panel D. The values of $k_{c}$ for untreated samples (for $t$ from 0 to $5.3 \mathrm{~h}$ ) were $0.17 \pm 0.03 \mu \mathrm{M} \mathrm{O}_{2} \mathrm{~min}^{-1} \mathrm{mg}^{-1}$ and for treated samples (for $t$ from 0 to $4.5 \mathrm{~h}$ ) $0.16 \pm$ $0.02 \mu \mathrm{M} \mathrm{O}_{2} \mathrm{~min}^{-1} \mathrm{mg}^{-1}(p=0.3954)$. Cellular ATP at $t=0 \mathrm{~h}$ was $181.1 \pm 8.0 \mathrm{pmol} \mathrm{mg}^{-1}$. For untreated specimens, cellular ATP (in pmol mg ${ }^{-1}$, measured in triplicates) at $t=1.3 \mathrm{~h}$ was $33.9 \pm 1.7$, at $t=2.0 \mathrm{~h}$ was $61.2 \pm 1.4$, at $t=3.5 \mathrm{~h}$ was $32.6 \pm$ 1.4 , and at $t=5.3 \mathrm{~h}$ was $33.4 \pm 6.8$. For treated specimens, cellular ATP at $t=0.3 \mathrm{~h}$ was $66.5 \pm 3.9$, at $t=3.0 \mathrm{~h}$ was $58.0 \pm 7.4$ and at $t=4.5 \mathrm{~h}$ was $21.6 \pm 6.1$. Thus, the overall ATP contents for untreated samples (for $t$ from 1.3 to $5.3 \mathrm{~h}$ ) were $40.3 \pm 14.0$ and for treated samples (for $t$ from 0.3 to $4.5 \mathrm{~h}) 48.7 \pm 23.9(p=0.7754)$. In another experiment, ATP contents at $6 \mathrm{~h}$ for untreated tissue were $10.5 \pm$ $1.0(n=4)$ and for treated tissue $16.6 \pm 0.9(n=4)$. Thus, hepatocyte ATP was highest immediately after tissue collection (in vivo levels of hepatocyte bioenergetics) and declined equally in the presence and absence of atorvastatin (in vitro levels of hepatocyte bioenergetics).

\section{Hepatocyte caspases in liver tissue treated with atorvastatin}

Representative experiments for hepatocyte caspase activity in TO (Panels A-B) and C57BL/6 (Panels C-D) strains are shown in Figure 2. The samples were incubated at $37^{\circ} \mathrm{C}$ with and without $1.0 \mu \mathrm{M}$ atorvastatin for $6 \mathrm{~h}$. The specimens were then incubated at $37^{\circ} \mathrm{C}$ with $37 \mu \mathrm{M}$ Ac-DEVD-AMC in the presence and absence of zVAD-fmk $(32 \mu \mathrm{M})$. In untreated samples from the TO strain (Panel A), the AMC peak area (arbitrary unit, reflecting caspase activity) without zVAD was $1,627,780 \mathrm{mg}^{-1}$ and with zVAD was $121,952 \mathrm{mg}^{-1}$ (93\% inhibition). In treated samples (Panel B), the AMC peak area without zVAD was $963,346 \mathrm{mg}^{-1}$ and with zVAD was $152,144 \mathrm{mg}^{-1}$ (84\% inhibition). In untreated samples from the C57BL/6 strain (Panel C), the AMC peak area without zVAD was $1,988,712 \mathrm{mg}^{-1}$ and with zVAD $125,667 \mathrm{mg}^{-1}$ (94\% inhibition). In treated samples (Panel D), the AMC peak area without zVAD was 2,068,736 $\mathrm{mg}^{-1}$ and with zVAD 119,295 $\mathrm{mg}^{-1}$ (94\% inhibition). Thus, hepatocyte caspase activity at $6 \mathrm{~h}$ was similar in untreated and treated samples.

\section{Urea synthesis by liver tissue treated with atorvastatin}

Liver specimens were incubated at $37^{\circ} \mathrm{C}$ in $50 \mathrm{ml} \mathrm{KH}$ buffer (continuously gassed as above) with and without $1.0 \mu \mathrm{M}$ atorvastatin for $6 \mathrm{hr}$. Every $60 \mathrm{~min}$, specimens (sum sample weight $=86.9 \pm 5.9 \mathrm{mg}$ ) were removed from the incubation solutions and placed in $1.0 \mathrm{~mL} \mathrm{KH}$ buffer supplemented with $10 \mathrm{mM} \mathrm{NH}_{4} \mathrm{Cl}$ and $2.5 \mathrm{mM}$ ornithine. The solutions were then analyzed for urea at min 
50. The concentrations of urea $(\mathrm{mg} / \mathrm{dL}$ per $\mathrm{mg}$ liver tissue) for untreated and treated samples were not significantly different (Table 1).

\section{Histology}

Representative micrographs of hematoxylin and eosin stained sections of untreated tissue at 0 and $6 \mathrm{hr}$ and tissue treated with $1.0 \mu \mathrm{M}$ atorvastatin at $6 \mathrm{hr}$ are shown in Figure 3. The incubation conditions were as above. Liver architecture and cytology were preserved in treated and untreated specimens. Inflammation and cholestasis were absent.

\section{Discussion}

Asymptomatic increase in hepatic transaminases is most common adverse event of atorvastatin, occurring in
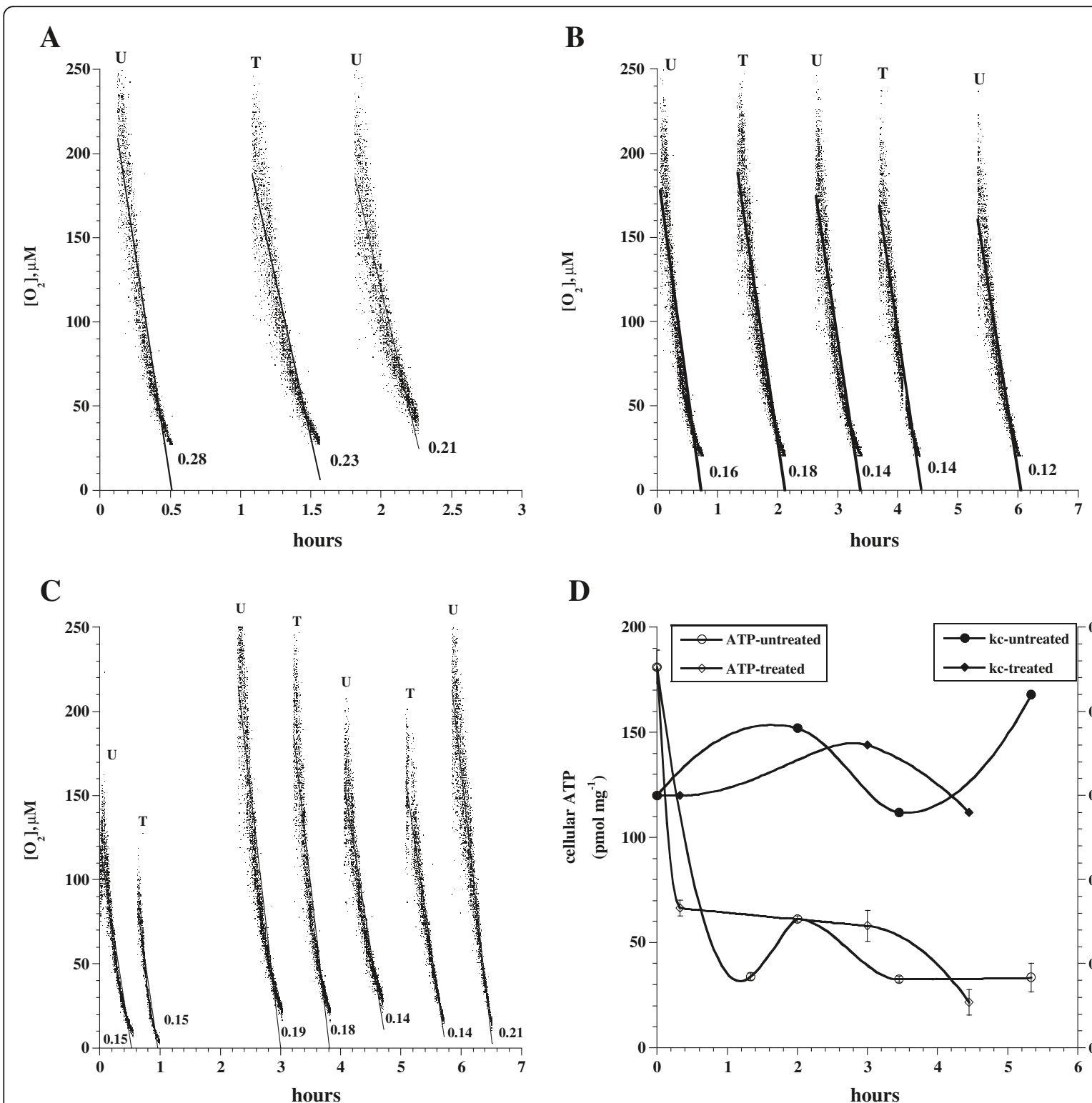

D

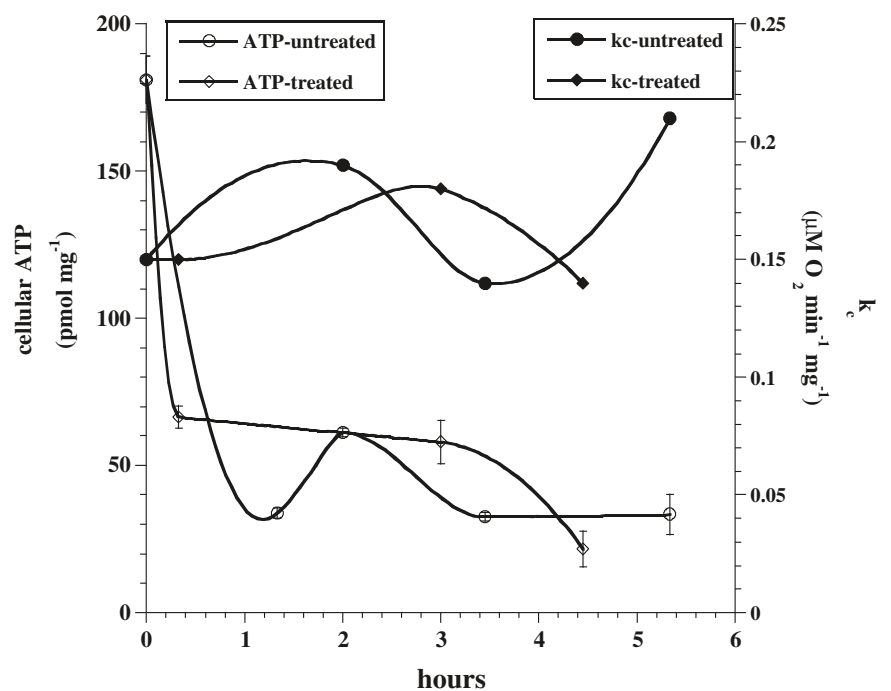

Figure 1 Atorvastatin neither alters hepatocyte respiration nor hepatocyte ATP content. Panels A-C: Cellular mitochondrial $\mathrm{O}_{2}$ consumption with and without atorvastatin. Panels $\mathbf{A}-\mathbf{B}, \mathrm{O}_{2}$ runs with and without $150 \mathrm{nM}$ atorvastatin. Panel $\mathbf{C}, \mathrm{O}_{2}$ runs with and without $1.0 \mu \mathrm{M}$ atorvastatin. Panel D: Cellular ATP content and values of $k_{c}$ as a function of incubation time. Liver specimens from TO mice were incubated in vitro at $37^{\circ} \mathrm{C}$ in $50 \mathrm{~mL} \mathrm{KH}$ buffer (continuously gassed with $95 \% \mathrm{O}_{2}: 5 \% \mathrm{CO}_{2}$ ) with and without $150 \mathrm{nM}(\mathbf{A}-\mathbf{B})$ or $1.0 \mu \mathrm{M}(\mathbf{C}-\mathbf{D})$ atorvastatin. Cellular $\mathrm{O}_{2}$ consumption and ATP content were determined as a function of time; $t=0$ corresponded to tissue collection. The lines in Panels $\mathbf{A}-\mathbf{C}$ are linear fits $\left(0.873<R^{2}<0.955\right)$. The rate of respiration $\left(k, \mu \mathrm{M} \mathrm{O}_{2} \mathrm{~min}^{-1}\right)$ was set as the negative of the slope of $\left[\mathrm{O}_{2}\right]$ vs. $t$. The values of $k_{c}\left(\mu \mathrm{M} \mathrm{O}_{2} \mathrm{~min}^{-1} \mathrm{mg}^{-1}\right)$ are shown at the bottom of each run. The values of $k_{c}$ in Panel $\mathbf{C}$ and the cellular ATP content of the same experiment are plotted in Panel $\mathbf{D}$. Eleven independent experiments were done with the TO mice and 4 independent experiments were done with the C57BI/6 mice. U, untreated; T, treated. 


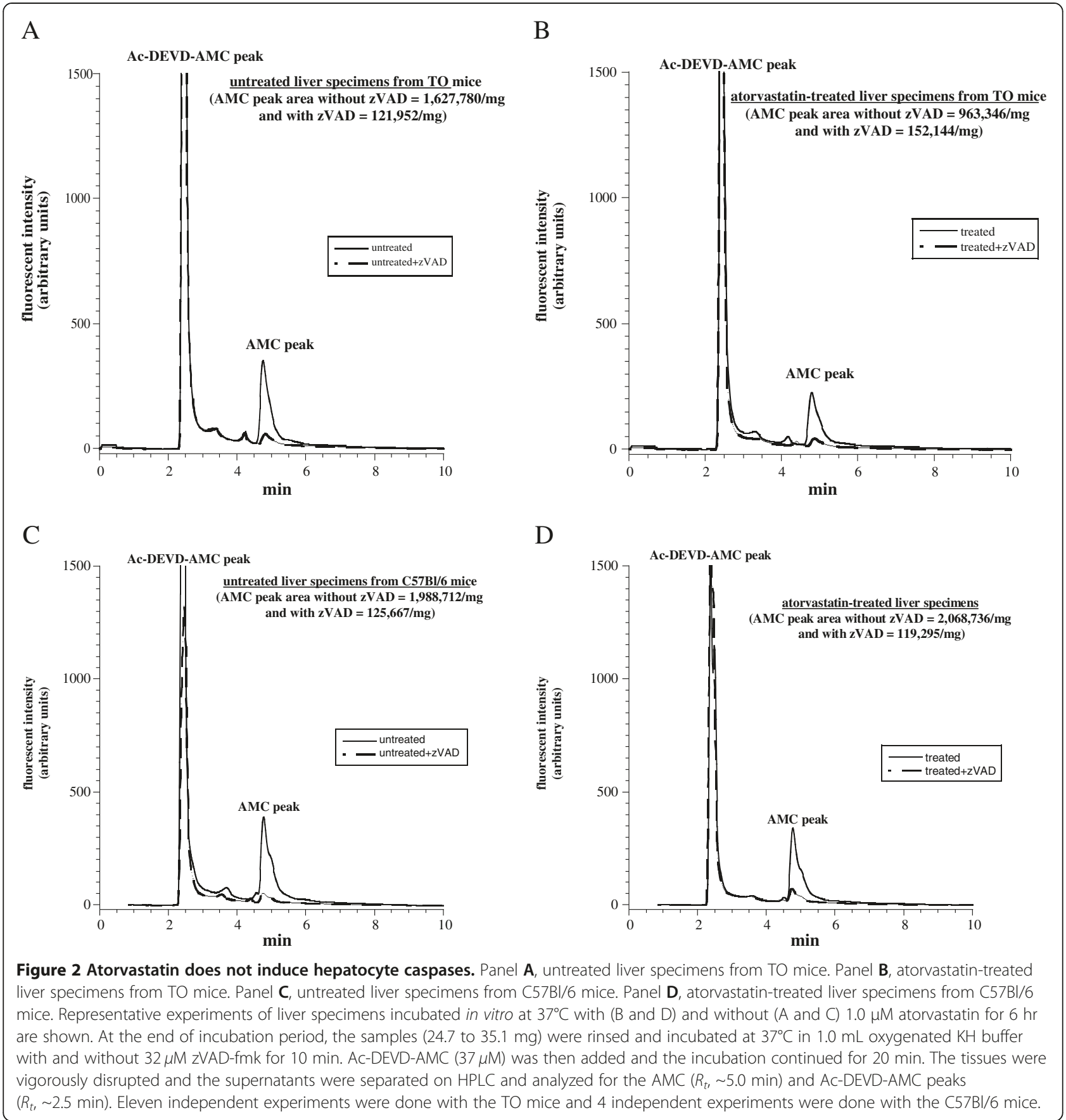

Table 1 Urea synthesis $\left(\mathrm{mg} / \mathrm{dL}^{\mathrm{mg}}{ }^{-1}\right.$, produced over $50 \mathrm{~min}$ ) by liver tissue treated with atorvastatin

\begin{tabular}{ccc}
\hline Untreated $(\mathbf{n}=6)$ & Treated $(\mathbf{n}=6)$ & $\boldsymbol{P}$-value \\
\hline $0.061 \pm 0.020$ & $0.072 \pm 0.022$ & 0.3866 \\
\hline
\end{tabular}

Liver specimens were incubated at $37^{\circ} \mathrm{C}$ in $\mathrm{KH}$ buffer with and without $1.0 \mu \mathrm{M}$ atorvastatin for $6 \mathrm{hr}$. Every $60 \mathrm{~min}$, specimens were removed from the incubation solutions and placed in $1.0 \mathrm{~mL} \mathrm{KH}$ buffer supplemented with $10 \mathrm{mM} \mathrm{NH}_{4} \mathrm{Cl}$ and $2.5 \mathrm{mM}$ ornithine. The solutions were then analyzed for urea at $\min 50$. The values are mean \pm SD for hr 1 to 6 . about $0.5 \%$ of patients [1]. Other hepatocellular injuries, such as cholestasis, immune hepatitis and fulminant liver failure are also possibly linked to atorvastatin use (Bhardwaj and Chalasani [7]; see also atorvastatin product insert). The duration between exposure and onset of toxicity varies, ranging from 12 hours to 52 weeks. The transaminase elevations, however, are frequently dose-dependent and occur in the first 16 weeks of therapy [3,24]. 


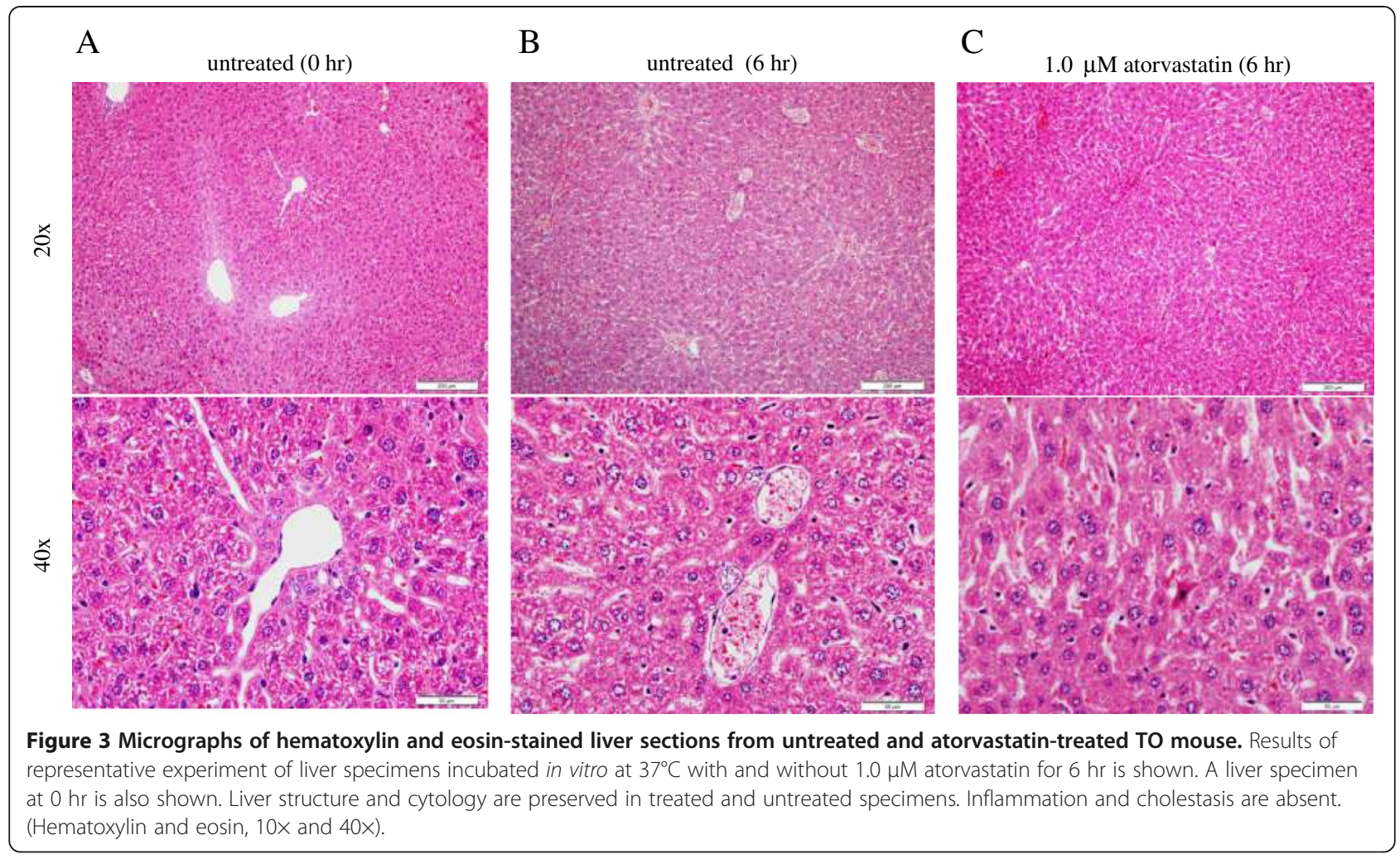

Oxygen consumption is sensitive to reduced cellular metabolic fuels, as well as to mitochondrial derangements. Cellular respiration is reduced in the presence of nutrient depletion or electron transport chain deficits. The rate of respiration, on the other hand, is enhanced in the presence of proton leak (uncoupling oxidative phosphorylation). As shown previously, measurements of cellular mitochondrial oxygen consumption by the phosphorescence oxygen analyzer are highly sensitive to these cellular insults [17]. Moreover, liver architecture and urea synthesis are typical biomarkers for assessing hepatocyte injury [25].

Hepatotoxicities were evident in diabetic and hypercholesterolemic rats treated with oral atorvastatin (5 $\mathrm{mg} / \mathrm{kg}$ daily) for two months [14]. Several reports also described statin-induced mitochondrial toxicities (see Dykens and Will [26]). More recently, impaired mitochondrial oxidative phosphorylation, membrane fluidity and coenzyme Q (ubiquinone, a component of the mitochondrial respiratory chain) content were reported in rats treated with $80 \mathrm{mg} / \mathrm{kg}$ atorvastatin for 4 weeks. The authors suggested that impaired hepatocyte bioenergetics may play a role in the development of statin-induced hepatotoxicities [15].

Atorvastatin also exerts cytotoxic effects on human hematopoietic tumors by promoting apoptosis through the mitochondrial cell death pathway. Other potential mechanisms involve altering the membrane localization of small GTPases. Treatment with statin resulted in reduction of mitochondrial membrane potential and cytosolic release of the activator of caspases Smac/DIABLO. As a result, caspases 9, 3 and 8 were efficiently activated [27].

This study investigated whether atorvastatin impairs hepatocyte cellular bioenergetics (respiration and ATP content). Strain-specific drug toxicities have been described [28]. Therefore, our animal model always tests different murine strains or a murine strain and a rat strain. The results clearly show preserved murine hepatocyte respiration and ATP content following in vitro exposure to $1.0 \mu \mathrm{M}$ atorvastatin for several hours (Figure 1). This concentration is about 20-fold higher than therapeutic plasma levels. Consistently, hepatocyte caspase activity (Figure 2) and liver architecture (Figure 3) are preserved in the presence of $1.0 \mu \mathrm{M}$ atorvastatin and indeed inflammation and cholestasis were absent. Thus, in the studied murine hepatic model, atorvastatin was not toxic. It is unknown, however, whether a much longer exposure produces cytotoxicity and will definitely be a venture for future research.

Cellular ATP was highest immediately after tissue collection (reflecting in vivo levels of bioenergetics) and declined subsequently to a new steady state (reflecting in vitro levels of bioenergetics), Figure 1D. This assumption is consistent with the preserved hepatocyte structure (Figure 3) and ultrastructure (data not shown) following tissue collection. Along the same lines, about $50 \%$ decline in cortical ATP levels was noted in rat brain 
15 min following cortical surgery [29]. The in vitro levels of ATP shown in Figure 1D, however, are much higher than those reported for cultured rat hepatocytes at the steady state level $\left(2.44 \pm 0.09 \mathrm{pmol} \mathrm{mg}^{-1}\right)$ [25].

Urea synthesis is a sensitive biomarker for hepatocellular functions. As shown in Table 1, the presence of atorvastatin for up to $6 \mathrm{hr}$ had no significant effect on the rate of hepatocyte urea synthesis. Consistently, hepatocyte structure was preserved in the presence of atorvastatin (Figure 3).

Statins inhibit the rate-limiting step of cholesterol biosynthesis catalyzed by HMG-CoA reductase. This inhibition leads to decreased hepatic cholesterol synthesis, up-regulation of low-density lipoprotein (LDL) receptor, and increased clearance of plasma LDL-cholesterol. As a result of inhibiting HMG-CoA reductase, statins could also inhibit the synthesis of important isoprenoids, such as farnesylpyrophosphate (FPP) and geranylgeranylpyrophosphate (GGPP). These intermediates serve as lipid attachments for the post-translational modification of intracellular proteins, such as nuclear lamins, Ras, Rho, Rac and Rap [30]. Hence, the pleiotropic effects of statins may arise from combined cholesterol lowering effects and inhibition of intracellular isoprenoiddependent proteins.

\section{Conclusion}

In conclusion, this in vitro study shows that murine hepatocyte bioenergetics, caspase activity and histology are preserved in the presence of high concentrations of atorvastatin for at least 6 hours. These observations are consistent with the fact that long term atorvastatin therapy is well tolerated clinically [8-10].

In pre-clinical drug development, in vitro studies are routinely performed prior to in vivo testing. Due to potential pharmacodynamic differences, in vitro pharmacological studies should be followed by in vivo testing. The biomarkers (hepatocyte bioenergetics and caspase activity) described in this study, however, can be easily adapted for in vivo studies. Moreover, due to potential species differences in response to atorvastatin, liver tissue from small and large animals (e.g., rats and monkeys) are needed for better prediction of organ toxicity.

\section{Competing interests}

The authors declare that they have no competing interests.

\section{Authors' contributions}

ASA and BA designed the study, carried out the analysis, interpreted the data and drafted the manuscript. SA and AA performed the histology. AKS supervised the progress and critically revised the manuscript. All authors read and approved the final manuscript.

\section{Acknowledgements}

This work was supported by a research grant from Sheikh Hamdan Bin Rashid Al Maktoum Award for Medical Sciences.

\section{Author details}

${ }^{1}$ Department of Internal Medicine, United Arab Emirates University, Al Ain, Abu Dhabi, United Arab Emirates. ${ }^{2}$ Department of Pathology, United Arab
Emirates University, Al Ain, Abu Dhabi, United Arab Emirates. ${ }^{3}$ Department of Pediatrics, United Arab Emirates University, Al Ain, Abu Dhabi, United Arab Emirates.

Received: 26 December 2012 Accepted: 22 February 2013

Published: 28 February 2013

\section{References}

1. Newman CB, Palmer G, Silbershatz $H$, et al: Safety of atorvastatin derived from analysis of 44 completed trials in 9,416 patients. Am J Cardiol 2003, 92:670-676.

2. Armitage J: The safety of statins in clinical practice. Lancet 2007, 370:1781-1790.

3. Liu Y, Cheng Z, Ding L, Fang F, Cheng KA, Fang Q, Shi GP: Atorvastatininduced acute elevation of hepatic enzymes and the absence of crosstoxicity of pravastatin. Int J Clin Pharmacol Ther 2010, 48:798-802.

4. Gillett RC, Norrell A: Considerations for safe use of statins: liver enzyme abnormalities and muscle toxicity. Am Fam Physician 2011, 83:711-716.

5. Law M, Rudnicka AR: Statin safety: a systematic review. Am J Cardiol 2006, 97:52C-60C

6. Brown W: Safety of statins. Curr Opin Lipidol 2008, 19:558-562.

7. Bhardwaj SS, Chalasani N: Lipid lowering agents that cause drug-induced hepatotoxicity. Clin Liver Dis 2007, 11:597-613.

8. Musso G, Cassader M, Gambino R: Cholesterol-lowering therapy for the treatment of nonalcoholic fatty liver disease: an update. Curr Opin Lipidol 2011, 22:489-496.

9. Tandra S, Vuppalanchi R: Use of statins in patients with liver disease. Curr Treat Options Cardiovasc Med 2009, 11:272-278.

10. Zamor PJ, Russo MW: Liver function tests and statins. Curr Opin Cardiol 2011, 26:338-341.

11. Argo CK, Loria P, Caldwell SH, Lonardo A: Statins in liver disease: a molehill, an iceberg, or neither? Hepatology 2008, 48:662-669.

12. Lewis JH, Mortensen ME, Zweig S, Fusco MJ, Medoff JR, Belder R: Efficacy and safety of high-dose pravastatin in hypercholesterolemic patients with well-compensated chronic liver disease: Results of a prospective, randomized, double-blind, placebo-controlled, multicenter trial. Hepatology 2007, 46:1453-1463.

13. Athyros VG, Tziomalos K, Gossios TD, et al: Safety and efficacy of long-term statin treatment for cardiovascular events in patients with coronary heart disease and abnormal liver function tests in the GREACE study: a post-hoc analysis. Lancet 2010, 376:1916-1922.

14. El-Hossary GG, El-Shazly AHM, Mohamed AS, Mansour SM: Evaluation of therapeutic potential of atorvastatin against diabetic retinopathy: $A$ biochemical histopathological study. J App/ Sci Res 2011, 7:1527-1535.

15. Ulicna O, Vancova O, Waczulikova I, Bozek P, Sikurova L, Bada V, Kucharska J: Liver mitochondrial respiratory function and coenzyme $Q$ content in rats on a hypercholesterolemic diet treated with atorvastatin. Physiol Res 2012, 61:185-193.

16. Ricci JE, Muñoz-Pinedo C, Fitzgerald P, Bailly-Maitre B, Perkins GA, Yadava N, Scheffler IE, Ellisman MH, Green DR: Disruption of mitochondrial function during apoptosis is mediated by caspase cleavage of the p75 subunit of complex i of the electron transport chain. Cell 2004, 117:773-786.

17. Tao Z, Penefsky HS, Goodisman J, Souid AK: Caspase activation by cytotoxic drugs (the caspase storm). Mol Pharm 2007, 4:583-585.

18. Alsamri MT, Alshamsi M, Al-Salam S, Marzouqi F, Al Mansouri A, Alhammadi S, Balhaj G, Al Dawaar SK, Al Hanjeri RS, Benedict S, Sudhadevi M, Conca W, Penefsky HS, Souid AK: Measurement of oxygen consumption by murine tissues in vitro. J Pharmacol Toxicol Meth 2011, 63:196-204.

19. Alshamsi M, Alsamri M, Al-Salam S, Conca W, Benedict S, Sudhadevi M, Biradar A, Asefa T, Souid AK: Biocompatibility study of mesoporous silicate particles with cellular bioenergetics in murine tissues. Chem Res Toxicol 2010, 11:1796-1805.

20. Shaban S, Marzouqi F, Almansouri A, Penefsky H, Souid AK: Oxygen measurements via phosphorescence. Comput Meth Programs Biomed 2010, 100:265-268.

21. Lo LW, Koch CJ, Wilson DF: Calibration of oxygen-dependent quenching of the phosphorescence of Pd-meso-tetra (4-carboxyphenyl) porphine: A phosphor with general application for measuring oxygen concentration in biological systems. Anal Biochem 1996, 236:153-160.

22. Takeyori S, Nobuhiko K: Analysis of regulatory factors for urea synthesis by isolated perfused rat liver. J Biochem 1975, 77:659-669. 
23. Maier K, Hofmann U, Bauer A, Niebel A, Vacun G, Reuss M, Mauch K: Quantification of statin effects on hepatic cholesterol synthesis by transient (13)C-flux analysis. Metab Eng 2009, 11:292-309.

24. Clarke AT, Mills PR: Atorvastatin associated liver disease. Digestive and liver disease official journal of the Italian Society of Gastroenterology and the Italian Association for the Study of the Liver 2006: Retrieved from http://www.ncbi. nlm.nih.gov/pubmed/16777499.

25. Berry MN: Metabolic properties of cells isolated from adult mouse liver. J Cell Biol 1962, 15:1-8.

26. Dykens JA, Will Y: The significance of mitochondrial toxicity testing in drug development. Drug Discov Today 2007, 12:777-785.

27. Cafforio P, Dammacco F, Gernone A, Silvestris F: Statins activate the mitochondrial pathway of apoptosis in human lymphoblasts and myeloma cells. Carcinogenesis 2005, 26:883-891

28. Lee GH, Nomura K, Kanda H, Kusakabe M, Yoshiki A, Sakakura T, Kitagawa T: Strain specific sensitivity to diethylnitrosamine-induced carcinogenesis is maintained in hepatocytes of $\mathrm{C} 3 \mathrm{H} / \mathrm{HeN}$ in equilibrium with $\mathrm{C} 57 \mathrm{BL} / 6 \mathrm{~N}$ chimeric mice. Cancer Res 1991, 15:3257-3260.

29. Marklund N, Salci K, Ronquist G, Hillered L: Energy metabolic changes in the early post-injury period following traumatic brain injury in rats. Neurochem Res 2006, 31:1085-1093.

30. Van Aelst L, D'Souza-Schorey C: Rho GTPases and signaling networks. Genes Dev 1997, 11:2295-2322.

doi:10.1186/2050-6511-14-15

Cite this article as: Alfazari et al:: Bioenergetic study of murine hepatic tissue treated in vitro with atorvastatin. BMC Pharmacology and Toxicology 2013 14:15.

\section{Submit your next manuscript to BioMed Central and take full advantage of:}

- Convenient online submission

- Thorough peer review

- No space constraints or color figure charges

- Immediate publication on acceptance

- Inclusion in PubMed, CAS, Scopus and Google Scholar

- Research which is freely available for redistribution 